\title{
11
}

\section{Native Realities in an Imaginary World: Contemporary Kanaka Maoli Art at Aulani, A Disney Resort \& Spa}

\section{A. Marata Tamaira}

\section{Pixie dust over Hawai' $i$}

On 22 September 2011, after three years of planning and construction and an expenditure of US\$850 million, Aulani, A Disney Resort \& Spa opened its doors to Hawai'i's public with a twilight ceremony that included a theatrical extravaganza of oli (Hawaiian chant), ${ }^{1}$ hula, a performance by Hawaiian singer/songwriter Keali'i Reichel, and the presentation of a ceremonial 'umeke (bowl), into which the Chairman and CEO of Walt Disney Company Bob Iger and the Chairman of Walt Disney Parks and Resorts Tom Staggs poured sand and pixie dust to symbolise the joining of two cultures, Hawai'i and Disney, respectively.

\footnotetext{
1 Aulani is the latest addition to the Ko Olina Resort Community and Marina complex, a consortium of tourist accommodation and leisure-time facilities located in Kapolei on the leeward coast of $\mathrm{O}^{\prime} \mathrm{ahu}, \mathrm{Hawai}$ i.
} 
Before the vessel was formally transferred to the Vice President and Managing Director of Aulani for their stewardship, Iger proclaimed, 'We are now and for all time 'ohana, one family'.

Two months after the grand opening, I had the opportunity to stay at Aulani with my family and experience it first-hand. I came away from that encounter deeply ambivalent about Aulani's place in Hawai'i and skeptical of its use of Native culture as part of Disney's corporate strategy to attract tourists to the Islands. In her landmark publication, From a Native Daughter: Colonialism and Sovereignty in Hawai'i, Kanaka Maoli scholar Haunani-Kay Trask equates tourism in Hawai'i with the exploitation of Kānaka Maoli, ${ }^{3}$ declaring: 'To most Americans ... Hawai' $\mathrm{i}$ is theirs: to use, to take, and, above all, to fantasize about long after the experience [emphasis in original].' ${ }^{4}$ The deleterious impact of tourism on Native lives is, of course, not unique to Hawai'i but equally evident in other Pacific homelands. In her own critique of tourism, Tongan scholar Konai Helu Thaman refers to it as a 'process of cultural invasion' with links to colonialism. ${ }^{5}$ The parallel Thaman draws between tourism and colonialism is especially salient for Hawai' $i$, a land colonised and occupied by the United States. Having myself lived in the Islands for over a decade now, it is often difficult to see where tourism begins and American colonialism ends because they are so tightly intertwined. What is also difficult to discern is where indigenous engagement with the tourist industry constitutes complicity with the broader hegemonic power structure and where it functions as a form of strategic intervention. In this instance, the situation at the Aulani Resort is a noteworthy case to consider given that dozens of Kānaka Maoli were involved in its conceptualisation and development. Here, the participation of Kanaka Maoli consultants, practitioners and artists in the Aulani project could potentially be perceived as an endorsement of the tourist enterprise, which has had a devastating impact on Kanaka Maoli culture and lands. On the other

2 A video of the opening ceremony is available at: 'Aulani Grand Opening Ceremony Pt. 1', 2011, YouTube, 22 September. Online: www.youtube.com/watch?v=UnINYeljfC8 (accessed 19 February 2016).

3 I include the macron (i.e. Kānaka Maoli) to indicate its use as a plural noun, but when used as a singular noun and adjective, I omit the macron.

4 Haunani-Kay Trask, 1999, From a Native Daughter: Colonialism and Sovereignty in Hawai'i, Honolulu: University of Hawai'i Press, p. 136.

5 Konai Helu-Thaman, 1993, 'Beyond hula, hotels, and handicrafts: A Pacific Islander's perspective of tourism development', The Contemporary Pacific 5(1): 104-11, p. 104. 
hand, their involvement could be seen as a powerful assertion of Native agency to intervene in a colonial space. Focusing on my experience at Aulani as a point of reference offers an opportunity for considering some of the broader issues relating to how Kānaka Maoli negotiated this ambivalent co-presence of collusion and agency.

As a master of storytelling and fantasy creation, Disney has been a major contributor to the cinematic packaging of Hawai'i for American consumption with films like Hawaiian Holiday (1937), The Parent Trap: Hawaiian Honeymoon (1989), Johnny Tsunami (1999), Rip Girls (2000), and the animated feature Lilo and Stitch (2002). Of significant note concerning the latter production, Disney provoked the ire of Kānaka Maoli with its misappropriation of two mele inoa (sacred name chants) - composed to honour the last two monarchs of the Hawaiian Kingdom, King David Kalākaua and Queen Lili'uokalani- that were rearranged to create a song for the lead protagonist, Lilo. ${ }^{6}$

Such thefts of cultural heritage together with the flagrant misrepresentation of the land and the people are present in many of the Disney films mentioned above. Stereotypes of Hawai'i and Kanaka Maoli culture are designed to spark in the American imagination a sense of what is 'theirs' to experience in the 'Aloha State': sun, sand, surfing, Aloha shirts, 'ukulele-strumming Natives, swaying hula girls, and the ever-present welcoming Hawaiian host ready to bestow a lei on the inbound guest: all to the strains of a slack-key guitar.

However, in 2008, when Aulani was first being conceptualised by Disney's team of Imagineers ('designers' in the Disney lexicon), the question of how to responsibly and respectfully incorporate a Kanaka Maoli worldview into the fabricated, imaginary world of Disney became a pressing concern. Rather than relying on its own authority to weave a story around Aulani, Disney took a different approach: to draw from already present Native perspectives of culture and place. In one of many interviews he gave to promote the resort, Senior Vice President of Walt Disney Imagineering Joe Rohde stated, 'The look and feel of Aulani is inspired directly by Hawaiian culture itself.

6 Nina Mantilla, 2011, 'The new Hawaiian model: The native Hawaiian cultural trademark movement and the quest for intellectual property rights to protect and preserve Native Hawaiian Culture', Intellectual Property Brief 3(2): 26-41, p. 26. 
People come to these islands and what gives Hawai'i its identity except the Hawaiians. So we went directly to Hawaiian art, Hawaiian tradition, and Hawaiian story.' ${ }^{7}$

The strategy to foreground Native culture to forward corporate tourist business agendas is nothing new. In Reimagining the American Pacific, Rob Wilson notes: 'Tourism, for Hawai'i if not for Pacific sites more generally, depends on the globalization-of-the-local into a marketable image with lasting appeal, with enduring charm and mysterious claim to uniqueness [emphasis added].' ${ }^{8}$ But while a focus on the transformation of Native heritage into tourist commodity is critically important for illuminating the exploitative nature of tourism-and there is a large body of scholarship that deals with this - of equal value is the acknowledgement of indigenous involvement in this complex and negotiable process of exchange.

\section{Displaying native realities at Aulani}

Experiencing Aulani in the flesh, as I did shortly after it opened, it is hard not to be impressed by the grand scope of the place. Driving up to the main porte cochére, visitors encounter a lo'i (irrigated terrace) stocked with kalo, a plant that holds significant cultural value for Kānaka Maoli and which has sustained them for millennia. In designing Aulani - the name meaning 'messenger of the chief' - Disney worked closely with indigenous stakeholders, cultural consultants and artists to tell Hawai'i's story. One of the most notable features of the resort is its rich display of contemporary Kanaka Maoli art. With the guidance of Kanaka Maoli businesswoman and entrepreneur Maile Meyer, Disney commissioned more than 60 indigenous artists to produce works ranging from paintings, sculptures, murals, to customary pieces such as 'umeke, poi pounders and kapa implements. One of the artists, painter Meala Bishop, noted the underlying significance of the works of art being displayed in the resort: 'You're gonna have a glimpse through the Native Hawaiian person's eye of the epic story of Hawai'i. What we see our history as. And it's so different from the commercial,

7 Jeanenne Tornatore, 2011, Orbitz exclusive interview with Joe Rohde, Senior Vice President of Walt Disney Imagineering, YouTube, 23 September.

8 Rob Wilson, 2000, Reimagining the American Pacific: From South Pacific to Bamboo Ridge and Beyond, Durham, NC: Duke University Press, p. xv. 
kitschy Hawai'i that we're all used to. ${ }^{9}$ Through the involvement of Meyer, Bishop, and other indigenous contributors, a Kanaka Maolicentric story of the Islands is borne out at Aulani in a compelling way.

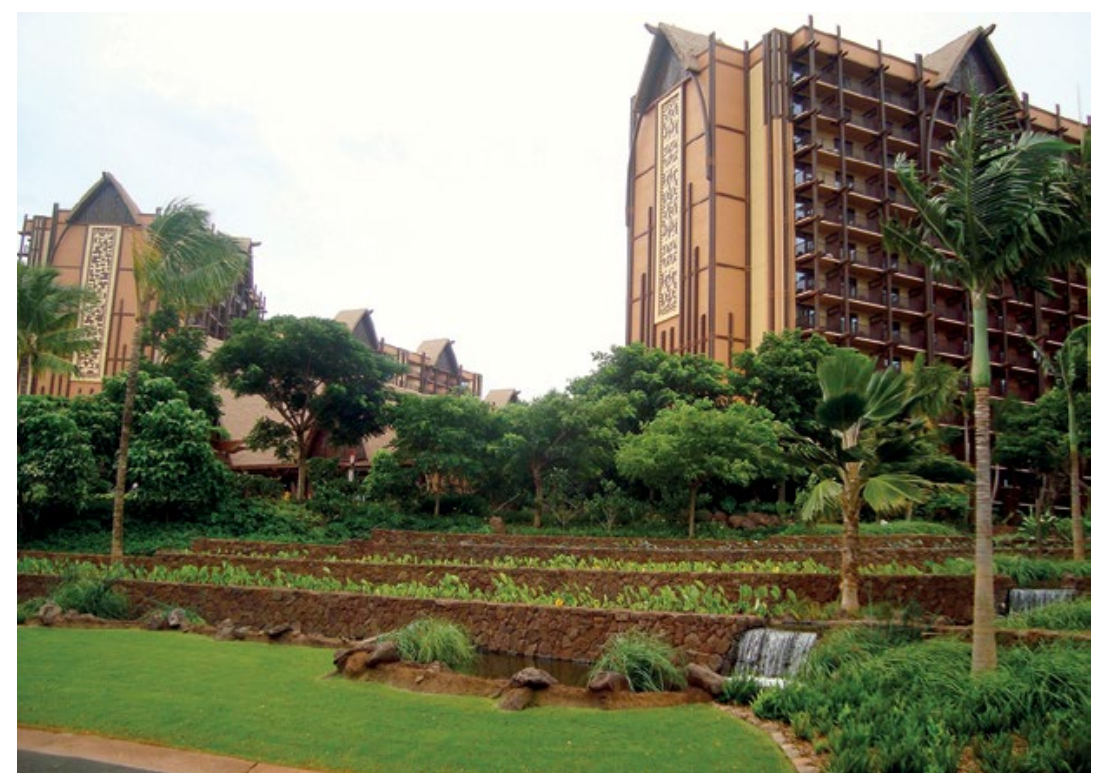

Figure 53. Exterior view of Aulani, A Disney Resort \& Spa with the lo'i kalo in the foreground.

Source. Photo by Marata Tamaira, 3 November 2011.

The largest works in the collection- eight 15-storey-high bas-reliefs, which furnish the exteriors of the two principle towers of the Aulani complex - were created by Carl F.K. Pao and Harinani Orme. In four of the bas-reliefs, Pao employed his own unique graphic writing style to render oli composed by artist and musician Doug Tolentino (who also served as a cultural consultant on the Aulani project). In the first two bas-reliefs, the Kanaka Maoli concept of balance between the male (Kū) and female (Hina) principles is invoked through the story of the rising and setting of the masculine sun and feminine moon. In following the recommendation of the artist and cultural consultants, Disney positioned the works in an east (male)-west (female) orientation to reflect the gender-encoded cardinal points of reference observed in Kanaka Maoli culture. The remaining two works by Pao-which face toward the mountains - pay tribute to two important individuals

9 Aulani, a Disney Resort \& Spa: Artist Interviews [video], n.d. 
of the area, respected kupuna (elder) Kamokila Campbell and famous seventeenth-century O'ahu chief Kākuhihewa. Orme's bas-reliefs, which look out toward the ocean and the mountains, are graphic representations of the story of Hina the moon goddess, the famous Polynesian trickster Maui and Hawaiian ocean voyaging.

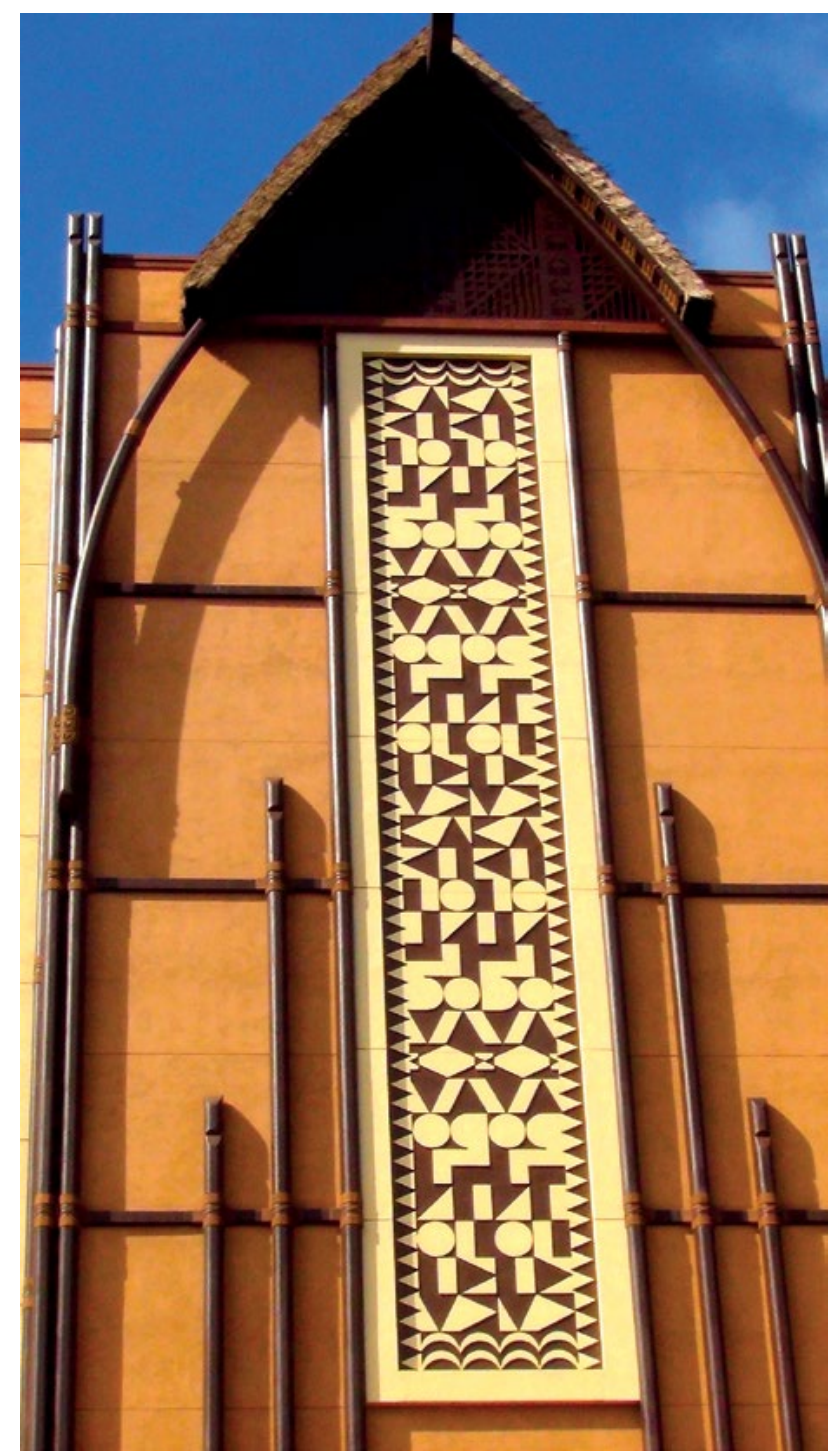

Figure 54. Untitled bas-relief based on a chant composed by Doug Tolentino in honour of the O'ahu chief Kākuhihewa, by Carl F.K. Pao, 2011. Source. Photo by Marata Tamaira, 3 November 2011. 
11. NATIVE REALITIES IN AN IMAGINARY WORLD

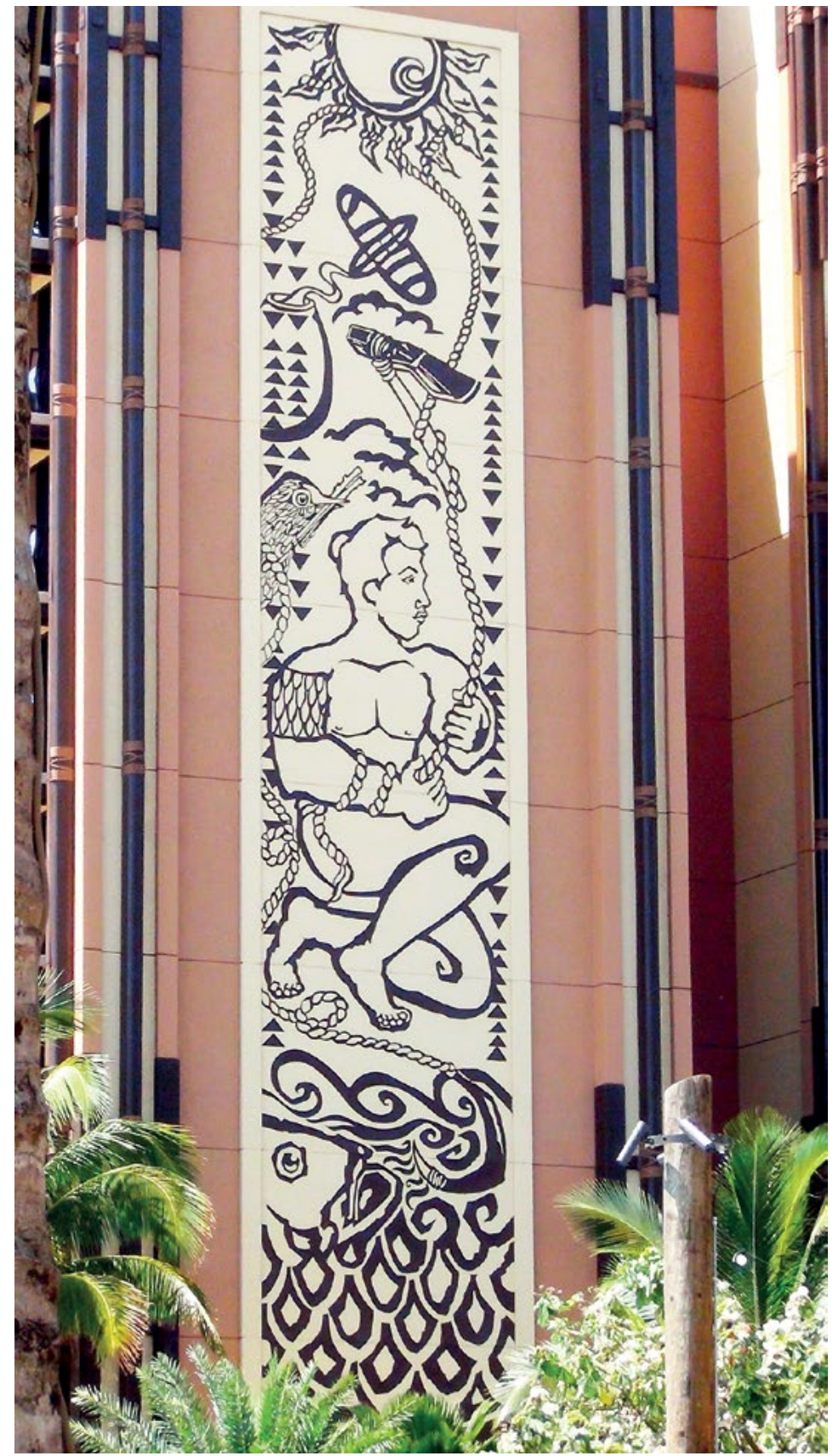

Figure 55. Untitled bas-relief based on the story of the demi-god Maui, by Harinani Orme, 2011.

Source. Photo by Marata Tamaira, 3 November 2011. 
Flanking the driveway that winds up to the entrance of Aulani, ki'i (sculpted images) by Rocky Jensen, Pat Pine and Jordan Souza stand like sentinels, their carved features a blend of customary and contemporary styles. They are not of the same order as the massproduced kitsch 'tikis' found in airports, bars, and tourist stores all over Hawai' $i$ and in other parts of the Pacific. Rather, the inspiration behind these works is rooted in the artists having a genealogical connection to the land and a deep understanding and commitment to their cultural heritage. This is what makes these ki'i mana-filled representations of contemporary Kanaka Maoli identity as opposed to rootless imitations. After being welcomed into Aulani's lobby by male and female 'Cultural Greeters' - some Kanaka Maoli, others local non-Kanaka Maoli-attired in beautifully patterned kīhei (cape-like garments worn over one shoulder), the visitor encounters Dalani Tanahy's kapa mural, a series of prints that symbolise the mutual principles of Kū and Hina. In one section of the work, Tanahy depicts Hina through three of the goddess' kinolau (physical manifestations). The top tier represents the different phases of the moon, the tier below represents the feet of the alae (the Hawaiian moorhen, a native bird of the Islands), and the bottom tier represents wana or sea urchin. At the apex of the lobby's cathedral-like transverse arches, Doug Tolentino's acrylic creations relay the epic stories of Pele (goddess of fire) and her sister Hi'iaka (goddess of hula), Kanaloa (god of the sea), and Kāne (god of procreation). Kanaka Maoli artworks are not confined to the resort's central area but also feature in private guest rooms, in the resort's restaurants, in public hallways, and at elevator alcoves. Aulani currently holds one of the largest collections of contemporary Maoli art in the world. 


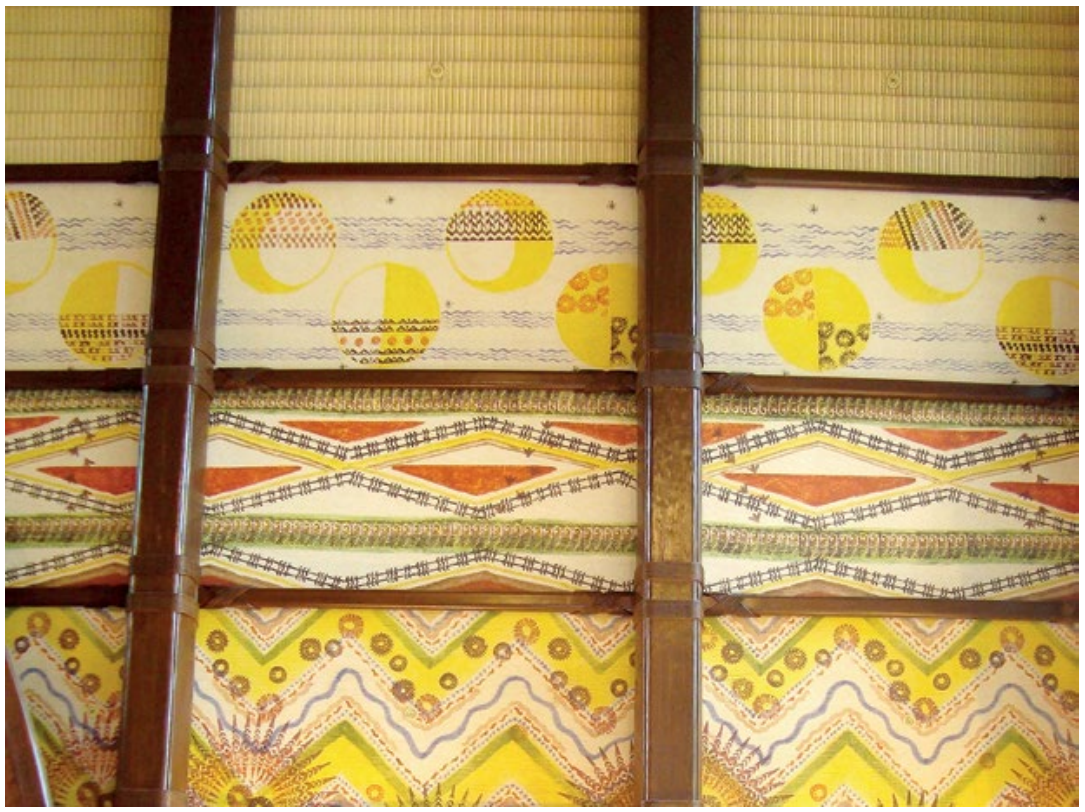

Figure 56. Kapa prints representing the goddess Hina, by Dalani Tanahy, 2011.

Source. Photo by Marata Tamaira, 3 November 2011.

\section{The complexities of claiming space}

In Hawai'i, where Kanaka Maoli artists struggle to find gallery space in which to exhibit their work, the display of such a large assemblage of indigenous art at Aulani might be seen as a positive development. Further, that a Kanaka Maoli perspective suffuses the conceptual and physical design of the resort is evidence of Disney's willingness to collaborate with the Native community, something that is lacking in other tourist venues. But that does not mean that Kanaka Maoli culture completely avoids being caught in 'a play of illusions and phantasms'.$^{10}$ The lo'i mentioned earlier, for instance, is a simulacrum in that the kalo plants, while undeniably real, are restricted to plastic pots rather than being planted in the ground. They grow, but not in any way that is sustainable - their roots have nowhere to go. A sign

10 Jean Baudrillard, 1994, Simulation and Simulacra, Ann Arbor: University of Michigan Press, p. 12. 
blocking the path to the lo'i further announces the illusion: 'Cast Members Only'. Further, menehune - a legendary people who are credited with building fishponds and temples throughout Hawai'iare trivialised by the display of small, plastic effigies of them, which are hidden all over Aulani's expansive grounds for guests to find. As for the beach on which Aulani is located, the fine sand is not natural to the area but rather has been imported from Australia to create the lagoon - one of four artificial ones in the Ko Olina complex - which was blasted and dug out in the 1980s when Ko Olina was first being developed. Indeed, Disney's invitation to guests to 'Relax on white sands, delight in gentle ocean breezes and play in peaceful ocean waters' met with the odiferous whiff of reality in April 2013 when Aulani was forced to close its lagoon after 1,000 gallons of raw sewerage spilled into the ocean near Ko Olina. ${ }^{11}$ In many ways, within this fog of fantasy, the ability of Kānaka Maoli to lay claim to Aulani as a space in which they can represent themselves is mediated by Disney's biased selection of stories and culture-reducing tropes that correspond with its own tourist selling point of Hawai'i as a place of charm and beauty. As a result, other Kanaka Maoli narratives are obscured.

From the hotel room I stayed in at Aulani, I had an unencumbered view of the Leeward Coast from my lanai. A short 16 kilometres (10 miles) away, I could see the communities of Nānākuli and Wai'anae. Predominantly Kanaka Maoli in terms of demography, both places are socially vibrant and rich in Hawaiian culture. However, they are also sites of economic hardship. The stretch of beach on which they are located has in parts been transformed into a string of 'tent cities' with families of homeless, many of whom are Kānaka Maoli, struggling to survive in a homeland where they can no longer afford housing. Further in the distance I could see Mākua Valley, a place that holds significant symbolic and cultural value for Kānaka Maoli and is the habitat of several endangered Native plants and animals. Since the 1930s, this important cultural site has been used as a target range for US military live-fire training exercises, resulting in the destruction of numerous sacred sites as well as biota found nowhere else on the planet. It goes without saying that these troubling realities are out of joint with the Aulani narrative that, as it says on the resort's official website, invites guests to immerse themselves in 'the legends of the

11 Aulani, a Disney Resort \& Spa, n.d. 
islands' so they 'can experience the true enchantment of Hawai' $i$ '. ${ }^{12}$ Aulani is just a few miles from Nānākuli, Wai'anae, and Mākua Valley, but once within the walls of the resort, tourists and local visitors alike are transported to an imaginary world far away.

Does this imply, then, that the Kanaka Maoli artists who were commissioned to help tell Hawai'i's story have been co-opted into a Disney rendition of the Islands, one that uses indigenous culture, history and tradition to sell the idea of a paradise that does not exist in reality? Indeed, does the participation of the artists - and the other Kānaka Maoli who collaborated on the project-help naturalise US colonialism in the Islands and neutralise the troubling realities faced by Kānaka Maoli every day? As Haunani-Kay Trask has so acutely observed, 'The political, economic, and cultural reality for most Hawaiians is hard, ugly, and cruel' ${ }^{13}$ On the surface, it could potentially be seen that way, and certainly such readings cannot be discounted. In fact, the participation of Native artists in the Aulani project was the topic of critique in the 2013 Maoli Arts Month exhibition "a" mini retort', held at the Arts at Mark's Garage in Honolulu. Curated by April Drexel, the aim of the show-which comprised an all-Kanaka Maoli lineup of artists - was to examine the "existing implications and nuances associated with "imaging" and "imagined" constructs' in specific relation to the characterisation of Hawaiian culture at the Aulani. ${ }^{14}$ One artist in particular, celebrated photographer Kapulani Landgraf, produced a strong retort in her installation titled 'Ka Maunu Pololoi? (The Right Bait?)'. The piece itself included over 40 springmounted rat traps located on the floor and attached to an entire single wall. Some of the traps were primed with faux money, while others had inkjet photographs of the commissioned Kanaka Maoli artworks at the Aulani fixed in the 'snap'. The printed text on the traps, 'LANI'which in Hawaiian means heavens, sky, elite, or spiritual—constituted a truncated version of the resort's name. The artist incorporated a stylised arch in the letter ' $\mathrm{A}$ ' in the text, a visual echo of Aulani's signature marketing logo.

12 'The Aulani Story', n.d., Aulani, Disney Resort and Spa. Online: resorts.disney.go.com/ aulani-hawaii-resort/about-aulani/story/ (accessed 18 February 2016).

13 Trask, From a Native Daughter, p. 137.

14 '“a” mini retort', 2013, Arts at Mark's Garage, Honolulu, Hawai`I, 30 April - 1 June. 
While the work revealed the bitter ideological divides extant in the Kanaka Maoli arts community regarding Native artistic engagement in the tourist industry in general and resorts in particular, Carl F.K. Pao views the inclusion of Native art at Aulani not as co-option or entrapment but as an articulation of Native agency in which Kānaka Maoli are empowered to tell their own stories and have a say in how their people and culture are represented. Pao notes, too, that although the Aulani artists might have been commissioned to produce works that were commensurate with Disney's vision, it did not prevent them from embedding in the works their own kaona, or hidden meaning. For example, in a series of painted panels he produced for one of Aulani's corridors, Pao depicted the god Kü's many kinolau. One of the motifs he used was a stylised phallus. The artist states, 'It represents one of the manifestations of Ku , but I also use it to symbolize Kanaka Maoli strength and potential in the face of colonialism' ${ }^{15}$ From Pao's perspective, his concealed mo'olelo (story/history) is a strategic intervention in the larger story told by Disney, a Native reality that he believes has potency.

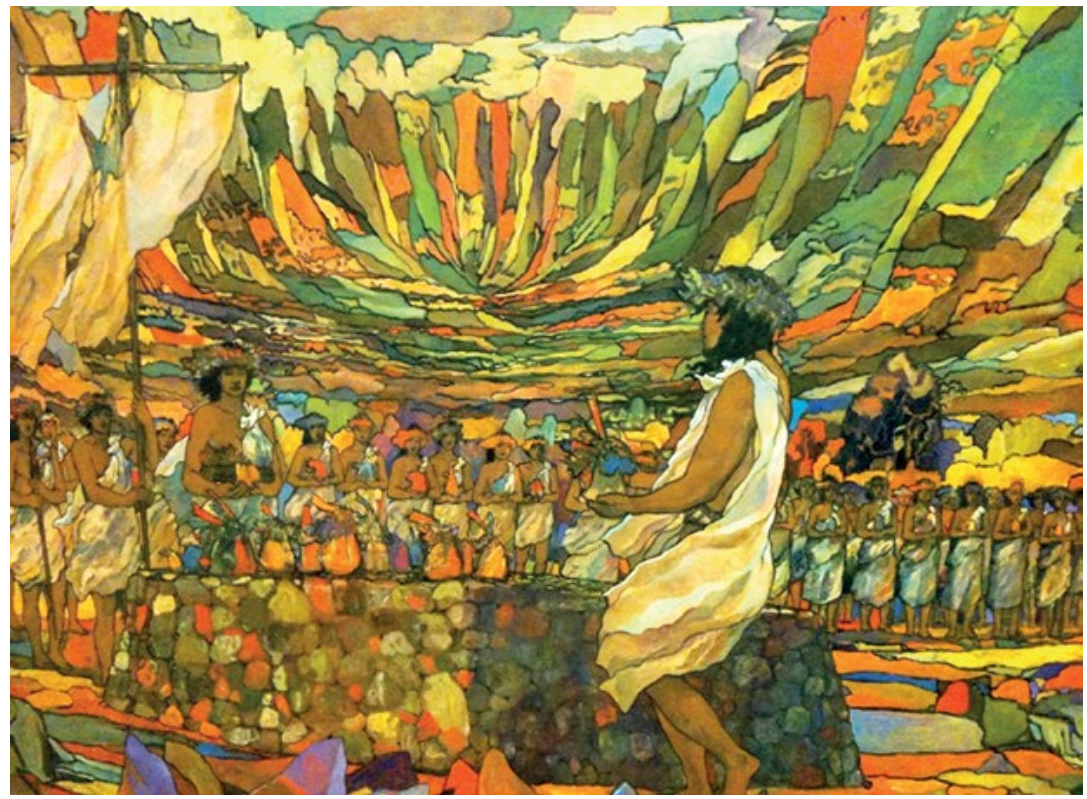

Figure 57. Makahiki mural, by Solomon Enos, 2011.

Source. Photo courtesy of the artist.

15 Carl F.K. Pao in interview with author, Honolulu, Hawai'i, 5 August 2012. 
Other Kānaka Maoli who participated in the project share Pao's empowering perspective. Fellow artist Solomon Enos created a vibrant mural for the Makahiki restaurant, which depicts the Makahiki ceremony in Mākua Valley. ${ }^{16}$ For Enos, the mural manifests a more empowering reality for Mākua than what currently exists: 'So you look at [Mākua] being a military reserve and the health and wellbeing of cultural and environmental ecosystems are threatened in this environment ... [By] drawing it as a thriving community, it becomes that much closer to being a thriving community again. ${ }^{17}$ In speaking about Aulani, Maile Meyer likens it to a loko i'a (fishpond), a traditional means by which Kānaka Maoli raised fish for food:

For me, I view those people [i.e., Aulani] as fish in a fishpond feeding our people ... That's my metaphor to survive. I think they can be fattened up and feed our people. As long as they stay contained. And, Aulani is a containment to me. As long as they don't make a left out the gate, to me I'm happy. Because they can stay contained, they can bring their dollars, they can help support our people by working the fishpond and by feeding our families with wages. They helped sustain and grow the arts community because as a result of those commissions at least 20 people in this town made enough money in a year or two to be able to choose to do more art if they wanted to ... I know that it's reordered the universe because more people are making art. ${ }^{18}$

For Meyer, partnering with corporate entities like Disney is part of a larger strategy not only to feed Kānaka Maoli but also to give them an affirmative presence in their own homeland by showcasing their culture through a rich body of visual artistic expression.

\section{Back to reality}

On the final day of my stay at Aulani, I sit in the lobby waiting for my husband to check us out of our suite. It is the early afternoon and I am looking forward to escaping the world of imagination and getting back to reality. We would never in a million years have thought to come to this place for a vacation, but my husband-Carl F.K. Pao, who is featured in this writing-along with several other Kanaka Maoli

\footnotetext{
16 The Makahiki is the Hawaiian New Year that is marked by festivities and peace.

17 Solomon Enos in interview with author, Honolulu, Hawai'i, 16 January 2013.

18 Maile Meyer in interview with author, Honolulu, Hawai'i, 24 September 2012.
} 
artists received a free three-night stay at the resort. While I wait, I take the opportunity to jot down some more notes about this perplexing place, where pixie dust and Native sand are brought together in seemingly artificial combination. As I write, a young man approaches me and introduces himself. He is one of several Kanaka Maoli hosts who welcome guests as they enter the resort. After chatting with him for several minutes I begin to feel comfortable enough to share my own opinions about the resort, touching on the positive aspects as well as the seeming contradictions. In response, the young man leans in, lowers his voice, and murmurs: 'There's a script [here], but no one's following it.'

At the time, the statement struck me as somewhat incendiary, mutinous even. Thinking about it now, I believe it illustrates one of several agentic ways Kānaka Maoli navigate the tourism milieu in which they find themselves. Whether through not following 'the script', inserting hidden meanings into a visual creation, or 'fishing' out resources to feed the people, this kind of agency and enterprise is part of a Native reality that is currently being played out in places like Aulani. At this point in time, the corporate tourism machine seems to have a permanent foothold in Hawai' $i$ (some might say it is less a foothold and more a stranglehold). Nevertheless, as with all foreign things that have come up on these shores, Kānaka Maoli have found ways to turn flotsam like Aulani into a tool of self-empowerment by using the resort as a space in which to tell the story of Hawai'i from their own perspective, significantly through the visual arts. It remains to be seen, however, just how long they are able to contain the exotic 'fish' that has swum into their waters, before it escapes the enclosure and, as Meyer states, 'make[s] a left out the gate'.

\section{References}

“'a" mini retort'. 2013. Arts at Mark's Garage. Honolulu, Hawai'i. 30 April - 1 June.

Aulani, a Disney Resort \& Spa: Artist Interviews [video]. n.d. Online: www.popscreen.com/v/5W6Tx/Aulani-a-Disney-Resort-SpaArtist-Interviews (accessed 11 March 2013, link subsequently removed). 
Aulani, a Disney Resort \& Spa. n.d. Online: resorts.disney.go.com/ aulani-hawaii-resort/activities-amenities/pools-beach/beach/ (accessed 13 August 2013).

Baudrillard, Jean. 1994. Simulation and Simulacra. Ann Arbor: University of Michigan Press.

Helu-Thaman, Konai. 1993. 'Beyond hula, hotels, and handicrafts: A Pacific Islander's perspective of tourism development.' The Contemporary Pacific 5(1): 104-111.

Mantilla, Nina. 2011. 'The new Hawaiian model: The native Hawaiian cultural trademark movement and the quest for intellectual property rights to protect and preserve Native Hawaiian Culture.' Intellectual Property Brief 3(2): 26-41.

'The Aulani Story.' n.d. Aulani, Disney Resort and Spa. Online: resorts.disney.go.com/aulani-hawaii-resort/about-aulani/story/ (accessed 18 February 2016).

'The Grand Opening Ceremony for Disney's Aulani Resort \& Spa in Ko Olina, Hawaii.' 2011. YouTube. 22 September. Online: www. youtube.com/watch?v=UnINYeljfC8 (accessed 19 February 2016).

Tornatore, Jeanenne. 2011. Orbitz exclusive interview with Joe Rohde, Senior Vice President of Walt Disney Imagineering. YouTube. 23 September. Online: www.youtube.com/watch? $\mathrm{v}=\mathrm{O} 2 \mathrm{stKOSSRF}$ 4\&feature=player_detailpage (13 August 2013).

Trask, Haunani-Kay. 1999. From a Native Daughter: Colonialism and Sovereignty in Hawai'i. Honolulu: University of Hawai'i Press.

Wilson, Rob. 2000. Reimagining the American Pacific: From South Pacific to Bamboo Ridge and Beyond. Durham, NC: Duke University Press. 
This text is taken from Touring Pacific Cultures, edited by Kalissa Alexeyeff and John Taylor, published 2016 by ANU Press, The Australian National University, Canberra, Australia. 